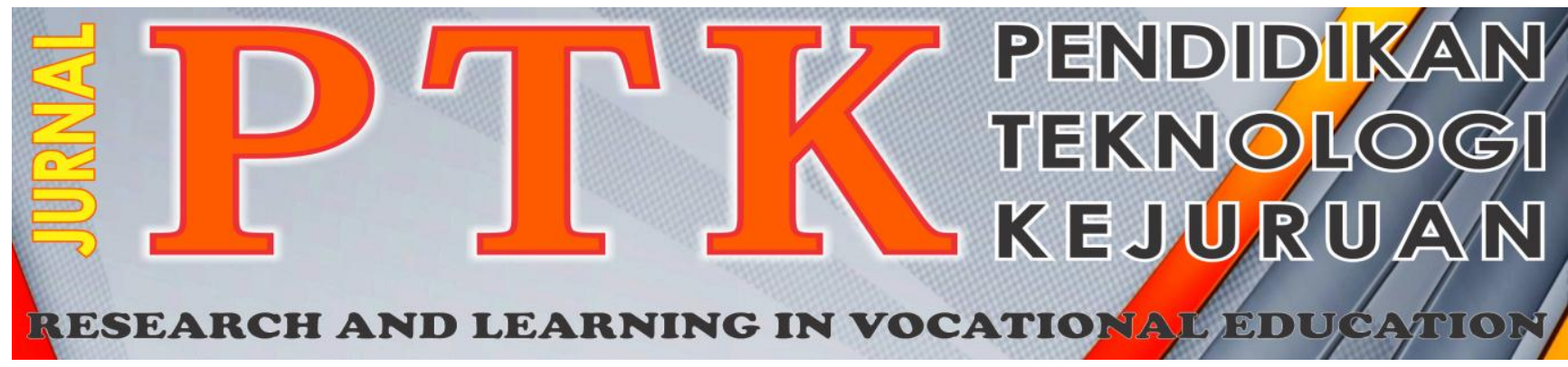

Vol. 1, No. 32018

\title{
PENGEMBANGAN MODUL PEMBELAJARAN INTERAKTIF APLIKASI ADOBE FLASH BAHASA JAVA PADA MATA PELAJARAN OBJECT ORIENTED PROGRAMMING (OOP)
}

\author{
Muhammad Ikram Jasman ${ }^{\text {* }}$, Kasman Rukun ${ }^{2}$ dan Sukardi ${ }^{3}$ \\ ${ }^{1}$ SMKN 1 Lahat \\ ${ }^{23}$ Universitas Negeri Padang \\ *Corresponding author, e-mail: ikramptikubh@gmail.com
}

\begin{abstract}
Abstrak - Tujuan dari penelitian ini adalah untuk mengembangkan modul pembelajaran interaktif yang bisa membantu siswa dalam belajar mandiri serta valid, praktis, dan efektif. Sehingga diharapkan dengan adanya modul ini siswa dapat belajar mandiri dimana dan kapan saja. Penelitian ini dilaksanakan menggunakan metode penelitian pengembangan Research and Development $(R \& D)$ dengan model pengembangan $4 \mathrm{D}($ four-D). Tahap penelitian meliputi define (tahap pendefinisian), design (tahap perancangan), develop (tahap pengembangan), dan disseminate (tahap penyebaran). Instrumen yang digunakan pada penelitian ini berupa angket yang digunakan untuk mengukur validitas dan praktikalitas. Sedangkan untuk mengukur efektifitas menggunakan instrumen tes berupa soal pilihan ganda. Modul pembelajaran interaktif ini dibuat dengan menggunakan Adobe Flash CS6. Hasil penelitian menunjukan bahwa modul pembelajaran interaktif dinyatakan valid dengan nilai kevalidan 0,89 berdasarkan validasi dari tiga orang validator media dan dari segi kevalidan materi dinyatakan valid dengan nilai 0,88 dari dua orang guru yang mengajar OOP. Modul pembelajaran interaktif dinyatakan sangat praktis berdasarkan respon guru dan siswa. Hal ini menunjukan bahwa, modul pembelajaran interaktif dinyatakan efektif digunakan sebagai salah satu bahan ajar dalam pembelajaran dalam meningkatkan hasil belajar siswa. Berdasarkan temuan penelitian dapat direkomendasikan bahwa modul pembelajaran interaktif merupakan salah satu alternatif bahan ajar dalam pembelajaran yang dapat di gunakan pada pembelajaran pada mata pelajaran Object Oriented Programming (OOP).
\end{abstract}

Kata kunci : Modul Pembelajaran Interaktif, PBO, OOP, Research and Development

Abstract-The purpose of this research is to develop interactive learning module that can help students in self-study as well as valid, practical, and effective. So hopefully with this module students can learn independently where and anytime. Research phase includes define, design, develop, and disseminate. The instrument used in this study was a questionnaire that used to measure validity and practicality. While measuring the effectiveness was by using the test instrument in the form of multiple choice questions. This interactive instructional module was created using Adobe Flash CS6. The results showed that Interactive Learning Module is valid based on the assessment of each with the value is 0,89 aspect by the three validators. Interactive Learning Module is considered very practical based on teacher and student responses. This shows that, Interactive Learning Module otherwise effective use as a medium of learning in improving student learning outcomes. Based on the research findings can be recommended that Interactive Learning Module is one of the alternative learning module that can be used on learning of OOP.

Keywords: Interactive Learning Module, PBO, OOP, Research and Development (R\&D).

\section{Pendahuluan}

Pembelajaran yang dilakukan diruang kelas yang dilaksanakan oleh guru dengan menggunakan perangkat pembelajaran sepert modul pembelajaran sebagai alat untuk menyampaikan materi ajar kepada siswa, sehingga hal ini dapat membantu siswa dalam melakukan proses belajar dan mengajar dengan baik dan efektif [1][2]. Penunjang dalam pembuatan modul pembelajaran tersebut telah banyak menggunakan Teknologi computer [3][4] Teknologi komputer yang digunakan dalam pembuatan modul pembelajaran dapat memudahkan guru dalam 
merancang sebuah proses pebelajaran di dalam kelas [5][6][7].

Modul pembelajaran yang sudah ada disesuaikan dengan kompetensi inti (KI) dan kompetensi dasar (KD) yang terdapat dalam silabus dimasing-masing mata pelajaran [8]. KIKD sangat mempengaruhi pencapaian dari sebuah pembelajaran sehingga dalam membuat sebuah perangkat pembelajaran dalam hal ini modul, guru juga harus menyesuaikannya dengan KIKD yang ada. Modul yang dibuat oleh guru hendaknya sesuai dengan KIKD sehingga berbanding lurus dengan hasil dan tujuan pembelajaran, namun penggunaan modul belum sepenuhnya mampu membantu siswa dalam belajar dilihat dari hasil ulangan harian, hasil ulangan keterampilan/praktik siswa dan Mid semester hampir separo dari siswa tidak mencapai ketuntasan.

Modul yang digunakan belajar oleh siswa masih terdapat beberapa kekurangan, diantaranya :

(1) modul yang sudah ada masih kurang menarik untuk di pakai dalam proses pembelajaran, karena modul yang sudah ada hanya menjelaskan teori secara tertulis tanpa ada simulasi penerapan sebuah pembelajaran terutama pembelajaran yang sifatnya praktik yang membutuhkan penerapan yang dituangkan dalam sebuah simulasi. (2) modul pembelajaran yang dipakai masih bersifat statis maksudnya ketika modul itu dipakai sulit bagi siswa untuk memahami maksud dari materi ajar yang diajarkan, maksud statis disini adalah dalam segi hal materi ajar hanya terfokus pada satu materi yang hanya ada didalam modul tersebut. (3) keterbatasan modul yang ada susah untuk diakses siswa diluar lingkungan sekolah. Ketika siswa sudah berada diluar lingkungan sekolah, maka siswa sulit untuk mengulang kembali pembelajaran yang telah disampaikan didalam kelas.

Oleh sebab itu, maka dikembangkan sebuah modul pembelajaran yang bisa mengatasi kekurangan yang sudah dijelaskan di atas dengan mengembangan Modul Interaktif Aplikasi Adobe Flash Bahasa Java Pada Mata Pelajaran Oriented Obyek Programmning (OOP) degan tujuan mengetahui proses pengembangan modul pembelajaran dengan aplikasi Adobe Flash, memahami penggunaan modul yang telah dibuat serta mengetui uji validitas, dan efektifitas dari modul pembelajaran yang telah dibuat.

Spesifikasi produk yang dikembangkan disesuaikan dengan perangkat pembelajaran yang terdiri dari silabus dan RPP, bahan pembelajaran, lembar tugas, dan lembar penilaian pembelajaran [9] [10]. Modul merupakan bahan ajar cetak yang dirancang untuk dapat dipelajari secara mandiri oleh peserta pembelajaran. Modul disebut juga Modul untuk belajar mandiri karena didalamnya telah dilengkapi dengan petunjuk untuk belajar sendiri. Artinya pembaca dapat melakukan kegiatan belajar tanpa kehadiran pengajar secara langsung [11].

Ciri-ciri atau karakteristik modul sesuai dengan pedoman adalah 1) Self Instructional; yaitu mampu membelajarkan siswa secara mandiri, 2) Self Contained; yaitu seluruh materi pembelajaran dari satu unit kompetensi atau sub kompetensi yang dipelajari terdapat di dalam satu modul secara utuh. Tujuan dari konsep ini adalah memberikan kesempatan pembelajar mempelajari materi pembelajaran yang tuntas, karena materi dikemas ke dalam satu kesatuan yang utuh, 3) Standalone (berdiri sendiri); yaitu modul yang dikembangkan tidak tergantung pada Modul lain atau tidak harus digunakan bersama-sama dengan Modul pembelajaran lain. Dengan menggunakan modul, pebelajar tidak tergantung dan harus menggunakan Modul yang lain untuk mempelajari dan atau mengerjakan tugas pada modul tersebut, 4) Adaptive; modul hendaknya memiliki daya adaptif yang tinggi terhadap perkembangan ilmu dan teknologi. Dikatakan adaptif jika modul dapat menyesuaikan perkembangan ilmu pengetahuan dan teknologi, serta fleksibel digunakan, 5) User Friendly, modul hendaknya bersahabat dengan pemakainya. Setiap instruksi dan paparan informasi yang tampil bersifat membantu dan bersahabat dengan pemakainya, termasuk kemudahan pemakai dalam merespon, mengakses sesuai dengan keinginan [12]

Komponen Modul mencakup tiga
bagian[11]

\section{Bagian pembuka}

a. Judul

Judul modul perlu menarik dan memberi gambaran tentang materi yang dibahas.

\section{b. Daftar Isi}

Daftar isi menyajikan topik-topik yang dibahas. Topik-topik tersebut diurutkan berdasarkan urutan kemunculan dalam modul.

c. Peta Informasi

Modul perlu menyertakan peta Informasi. Pada daftar isi akan terlihat topik apa saja yang dipelajari, tetapi tidak terlihat kaitan antar topik tersebut. Pada peta informasi akan diperlihatkan kaitan antar topik-topik dalam modul. Peta informasi yang disajikan dalam modul dapat saja menggunakan diagram isi bahan ajar yang telah dipelajari sebelumnya. 
d. Daftar Tujuan Kompetensi Umum

Penulisan tujuan kompetensi membantu pembelajar untuk mengetahui pengetahuan, sikap, atau keterampilan apa yang dapat dikuasai setelah menyelesaikan pelajaran.

\section{Bagian Inti (Kegiatan Belajar)}

a. Pendahuluan/Tinjauan Umum Materi

Pendahuluan pada suatu modul berfungsi untuk ; (1) memberikan gambaran umum mengenai isi materi modul, (2) meyakinkan pembelajar bahwa materi yang akan dipelajari dapat bermanfaat bagi mereka, (3) meluruskan harapan pembelajar mengenai materi yang akan dipelajari, (4) mengaitkan materi yang telah dipelajari dengan materi yang akan dipelajari, (5) memberikan petunjuk bagaimana mempelajari materi yang akan disajikan. Dalam pendahuluan dapat saja disajikan peta informasi mengenai materi yang akan dibahas dan daftar tujuan kompetensi yang akan dicapai setelah mempelajari modul.

b. Hubungan Dengan Materi atau Pelajaran Yang Lain

Materi pada modul sebaiknya lengkap, dalam arti semua materi yang perlu dipelajari tersedia dalam modul. Bila materi tersebut tersedia pada buku teks maka arahan tersebut dapat diberikan dengan menuliskan judul dan pengarang buku teks tersebut.

c. Uraian Materi

Uraian materi merupakan penjelasan secara terperinci tentang materi pembelajaran yang disampaikan dalam modul. Organisasikan isi materi pembelajaran dengan urutan dan susunan yang sistematis, sehingga memudahkan pembelajar memahami materi pembelajaran. Apabila materi yang akan dituangkan cukup luas, maka dapat dikembangkan ke dalam beberapa Kegiatan Belajar (KB). Setiap KB memuat uraian materi, penugasan, dan rangkuman.

Organisasi materi kegiatan belajar antara judul, sub judul dan uraian harus yang mudah untuk diikuti oleh pembelajar. Pemberian judul atau penjudulan merupakan alat bantu bagi pembaca modul untuk mempelajari materi yang disajikan dalam bentuk teks tertulis.

d. Penugasan

Penugasan dalam modul perlu untuk menegaskan kompetensi apa yang diharapkan setelah mempelajari modul. Penugasan juga menunjukkan kepada pebelajar bagian mana dalam modul yang merupakan bagian penting. e. Rangkuman

Rangkuman merupakan bagian dalam modul yang menelaah hal-hal pokok dalam modul yang telah dibahas. Rangkuman diletakkan pada bagan akhir modul.

\section{Bagian Penutup}

a. Glosarium atau daftar istilah

Glosarium berisikan definisi-definisi konsep yang dibahas dalam modul. Definisi tersebut dibuat ringkas dengan tujuan untuk mengingat kembali konsep yang telah dipelajari.

1) Tes Akhir

Tes akhir merupakan latihan yang dapat pembelajar kerjakan setelah mempelajari suatu bagian dalam modul. Aturan umum untuk tes akhir ialah bahwa tes tersebut dapat dikerjakan oleh pembelajar.

2) Indeks

Indeks memuat istilah-istilah penting dalam modul serta halaman di mana istilah tersebut ditemukan. Indeks perlu diberikan dalam modul supaya pebelajar mudah menemukan topik yang ingin dipelajari. Indeks perlu mengandung kata kunci yang kemungkinan pembelajar akan mencarinya.

Berdasarkan uraian di atas, pembelajaran dengan menggunakan modul lebih mempermudah siswa karena terdapat peta informasi atau panduan belajar sehingga siswa lebih tertarik dan termotivasi untuk belajar secara mandiri.

Teori Belajar Interaktif, Model pembelajaran interaktif sering dikenal dengan nama pendekatan pertanyaan anak. Model ini dirancang agar siswa akan bertanya dan kemudian menemukan jawaban pertanyaan mereka sendiri[13]. Meskipun siswa mengajukan pertanyaan dalam kegiatan bebas, pertanyaan-pertanyaan tersebut akan terlalu melebar dan seringkali kabur sehingga kurang terfokus. Guru perlu mengambil langkah khusus untuk mengumpulkan, memilah, dan mengubah pertanyaan-pertanyaan tersebut ke dalam kegiatan khusus. Pembelajaran interaktif merinci langkahlangkah ini dan menampilkan suatu struktur untuk suatu mata pelajaran yang melibatkan pengumpulan dan pertimbangan terhadap pertanyaan-pertanyaan siswa sebagai pusatnya[14]. Tahapan dalam model pembelajaran interaktif terdiri dari persiapan pengetahuan awal, kegiatan eksplorasi, pertanyaan siswa, penyelidikan, pengetahuan akhir dan refleksi.[15]

Kelebihan model pembelajaran interaktif diantaranya[16]: 
a. Siswa lebih banyak kesempatan untuk melibatkan keingintahuannya pada objek yang akan dipelajari.

b. Melatih siswa untuk mengungkapkan rasa ingin tahu melalui pertanyaan-pertanyaan yang diajukan siswa mupun guru.

c. Memberikan sarana bermain bagi siswa melalui kegiatan eksplorasi dan investigasi.

d. Guru sebagai fasilitator.

e. Guru Sebagai motivator.

f. Guru Sebagai perancang aktivitas belajar, Hasil belajar akan lebih bermakna.

Modul interaktif disamping memiliki karakteristik seperti pada bukul cetak namun disisi lain memiliki karakteristik interaktif tersendiri yang tidak terdapat pada bukul cetak. Semua ini berfungsi untuk memudahkan, meningkatkan motivasi dan efektifitas penggunaanya. Karakteristik modul interaktif yang berbeda dari modul biasa sebagai berikut.

a. Representasi Isi

b. Visualisasi dengan MultiModul (video, animasi, suara, teks, gambar)

c. Menggunakan variasi yang menarik

d. dan kualitas resolusi yang tinggi.

e. Tipe-tipe pembelajaran yang bervariasi.

f. Respon Pembelajaran dan Penguatan

g. Dapat digunakan secara klasikal atau individual.

Kriteria Modul Interaktif Berdasarkan urian di atas maka pengembangan modul interaktif mempertimbangkan beberapa kriteria sebagai berikut.

a. Daya coba tinggi

b. Menumbuhkan kreatifitas siswa

c. Visualisasi informasi yang besifat abstrak(tidak kasat mata)

d. Mengatasi Keterbatasan ruang dan waktu

e. Ada Stimulus - Respon

f. Meningkatkan motivasi belajar peserta diklat

g. Visualisasi relevan dengan materi

h. Kemasan Modul Interaktif

Kelebihan Pembelajaran dengan Menggunakan

Modul. Belajar menggunakan modul sangat banyak manfaatnya, siswa dapat bertanggung jawab terhadap kegiatan belajarnya sendiri, pembelajaran dengan modul sangat menghargai perbedaan individu, sehingga siswa dapat belajar sesuai dengan tingkat kemampuannya, maka pembelajaran semakin efektif dan efisien [17]. Beberapa keuntungan yang diperoleh jika belajar menggunakan modul, antara lain :

a. Motivasi siswa dipertinggi karena setiap kali siswa mengerjakan tugas pelajaran dibatasi dengan jelas dan yang sesuai dengan kemampuannya. b. Sesudah pelajaran selesai guru dan siswa mengetahui benar siswa yang berhasil dengan baik dan mana yang kurang berhasil.

c. Siswa mencapai hasil yang sesuai dengan kemampuannya.

d. Beban belajar terbagi lebih merata sepanjang semester.

e. Pendidikan lebih berdaya guna.

Selain itubeberapa keuntungan yang diperoleh dari pembelajaran dengan penerapan modul adalah sebagai berikut [18]

a. Meningkatkan motivasi siswa, karena setiap kali mengerjakan tugas pelajaran yang dibatasi dengan jelas dan sesuai dengan kemampuan.

b. Setelah dilakukan evaluasi, guru dan siswa mengetahui benar, pada modul yang mana siswa telah berhasil dan pada bagian modul yang mana mereka belum berhasil.

c. Bahan pelajaran terbagi lebih merata dalam satu semester.

d. Pendidikan lebih berdaya guna, karena bahan pelajaran disusun menurut jenjang akademik.

\section{Metode}

Metode yang digunakan dalam penelitian ini adalah metode Research and Development (R\&D). Penelitian dan pengembangan adalah metode penelitian yang digunakan untuk menghasilkan produk tertentu, dan menguji keefektifan produk tersebut [19].

Penelitian ini menggunakan rancangan penelitian pengembangan dengan model pengembangan four-D[20]. Four-D model ini terdiri dari 4 tahap utama yaitu, Define (Pembatasan), Design (Perancangan), Develop (pengembangan), dan Disseminate (Penyebaran). Salah satu alasan memilih model 4-D adalah karena model dengan pendekatan system ini sesuai dengan masalah yang melatar belakangi penelitian ini. Dengan adanya analisis kebutuhan (needs analysis), melihat karakteristik siswa, dan kelengkapan fasilitas yang ada maka diharapkan penelitian dengan modul ini dapat mengembangkan modul pembelajaran interaktif aplikasi Adobe Flash Bahasa Java pada mata pelajaran Object Oriented Programming (OOP) untuk siswa SMK jurusan Teknik Rekayasa Perangkat Lunak (RPL).

Uji Validitas dan Praktikalitas menggunakan instrument agket dalam penelitian serta untuk uji efektivitas menggunakan Pretest - Posttest Control Group Design. Teknik pengumpulan data yang digunakan untuk penelitian ini berupa instrumen tes tersebut untuk mengukur kemampuan mahasiswa sebelum dan setelah dilakukan proses pembelajaran. 


\section{HASIL DAN PEMBAHASAN}

Berdasarkan hasil penelitian ini adalah mengetahui validitas, praktikalitas, dan efektivitas modul pembelajaran interaktif aplikasi Adobe Flash bahasa Java pada mata pelajaran Object Oriented Programming (OOP) di SMK Negeri 1 Lahat. Pengembangan yang dilakukan menggunakan model pengembangan 4-D melalui empat tahapan pengembangan Modul yaitu: 1 . Tahap pendefinisian (Define); 2. Tahap Perancangan (Design); 3. Tahap Pengembangan (Develop); 4. Tahap Penyebaran (Disseminate).

\section{A. Tahap Pendefinisian (Define)}

Pada tahap ini ditemui masalah yang ada disekolah tersebut yaitu masih kurangnya pengetahuan siswa tentang materi pembelajaran yang diberikan, modul yang diberikan kepada siswa masih dalam versi yang lama tidak ada kemajuan pengetahuan yang terbaru. Guru masih menjadi sumber pengetahuan siswa, sehingga siswa hanya terfokus pada pengetahuan guru dan tidak mengetahui perkembangan yang terbaru.

\section{Observasi}

Observasi dilakukan pada mata pelajaran Object Oriented Programming (OOP) kelas XI jurusan Teknik Rekayasa Perangkat Lunak SMK Negeri 1 Lahat yaitu proses pembelajaran yang berlangsung masih berpusat kepada guru, hal ini dapat dilihat karena siswa bersikap pasif, hanya mengandalkan guru untuk mendapatkan materi pembelajaran, sehingga menyebabkan pembelajaran berlangsung secara monoton, hal ini menyebabkan siswa menjadi mudah bosan dan jenuh.

\section{Analisis kurikulum}

Analisis kurikulum ini mengacu pada RPP, dan silabus mata pelajaran Object Oriented Programming (OOP). Materi yang dikembangkan dalam modul pembelajaran interaktif adalah bagian dari Kompetensi Dasar dan Inti yang ada pada RPP dan silabus mata pelajaran Object Oriented Programming (OOP). KIKD yang dikembangkan adalah "Dasar Pemrograman Bahasa Java" pada RPP dan silabus mata pelajaran Object Oriented Programming (OOP), didalam KIKD tersebut terdapat delapan materi pokok, yaitu : 1) Paradigma pemrograman berorientasi obyek, 2) Perbandingan pemrograman procedural dan pemrograman berorientasi obyek, 3) Tipe data primitif, 4) Inisialisasi dan nilai default, 5) Operator, 6) Pengambilan keputusan, 7) Perulangan, 8) Class \& Obyek.

\section{Analisis siswa}

Didalam penelitian ini yang menjadi subjek adalah siswa kelas XI jurusan Teknik Rekayasa Perangkat Lunak SMK Negeri 1 Lahat. Siswa pada umumnya sudah mencapai usia 16 sampai 18 tahun. Para siswa tersebut memiliki kemungkinan dan kesempatan mengembangkan pengetahuan dan pemahaman sendiri. Oleh karena itu, pencapaian tahap ini memberi kemungkinan kepada siswa untuk belajar secara mandiri.

\section{B. Tahap Perancangan (Design)}

Tujuan tahap ini adalah untuk menyiapkan prototype perangkat pembelajaran. Tahap ini terdiri dari empat langkah yaitu

\section{Pengembangan tes acuan patokan}

Berdasarkan pada tujuan yang telah dirumuskan, maka dilakukan pengembangan butir asesmen untuk mengukur kemampuan siswa seperti yang diperkirakan di dalam tujuan. Tes ini disusun berdasarkan hasil perumusan khusus. Tes ini merupakan suatu alat mengukur terjadinya perubahan tingkah laku pada diri siswa setelah kegiatan belajar mengajar.

\section{Pemilihan Aplikasi}

Aplikasi yang digunakan dalam pengembangan modul pembelajaran interaktif bahasa java ini adalah Sofware Adobe Flash CS 6. Pembelajaran yang akan dilakukan adalah pembelajaran dengan menggunakan modul pembelajaran interaktif dimana siswa dapat mengasah keterampilan dan ketangkasannya dengan menggunakan perangkat yang telah disediakan. Adobe Flash dipilih untuk pembuatan fitur-fitur yang terdapat pada modul interaktif karena software ini sangat mendukung untuk pembuatan modul interaktif, pembuatan tombol dan dapat mengintegrasi teks, gambar, dan backsound.

\section{Merancang Prototype}

Rancangan prototype atau rancangan awal modul pembelajaran interaktif ini adalah rancangan yang harus dibuat sebelum dilakukannya validasi dan penelitian kelapangan. Pada tahap ini dilakukan penyusunan kerangka dalam modul pembelajaran interaktif berupa desain tampilan modul yang meliputi halaman pembuka, halaman home yang merupakan menu utama dari modul, halaman materi, halaman evaluasi yang berisi soal untuk menguji kemampuan siswa terhadap materi yang disajikan dalam modul. Hasil rancangan tampilan merupakan rancangan antar muka modul pembelajaran 
interaktif. Hasil rancangan tampilan modul pembelajaran interaktif tersebut terdiri dari:

a. Halaman pembuka dapat dilihat pada gambar berikut.

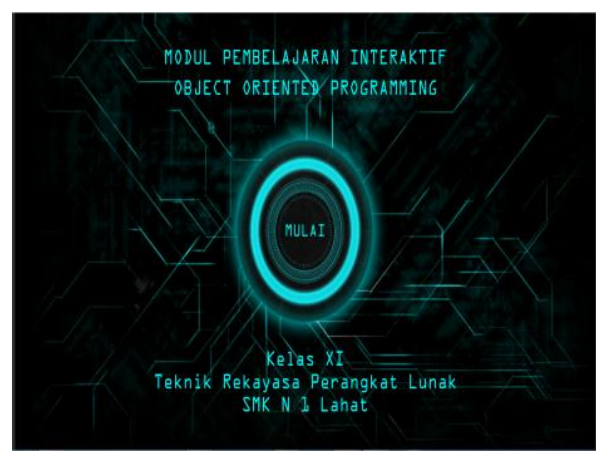

Gambar 1. Tampilan Halaman Intro

b. Halaman Menu Utama dapat dilihat pada gambar di bawah ini.

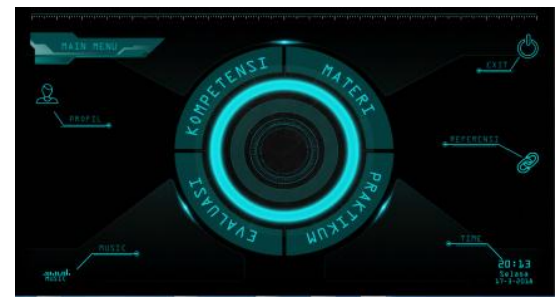

Gambar 2 Tampilan Halaman Menu Utama

c. Kompetensi merupakan halaman awal modul

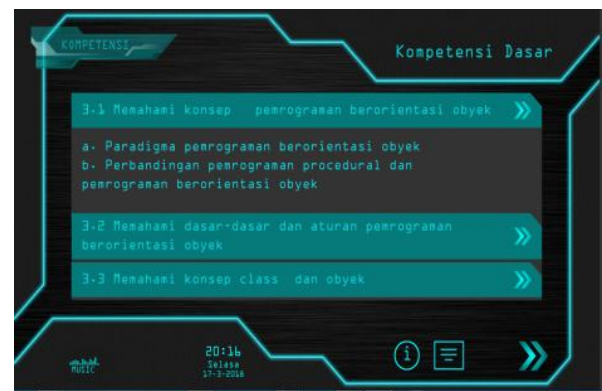

Gambar 3. Tampilan Halaman Kompetensi

d. Halaman menu materi, merupakan halaman yang berisikan materi-materi yang akan dipelajari pada gambar di bawah ini.

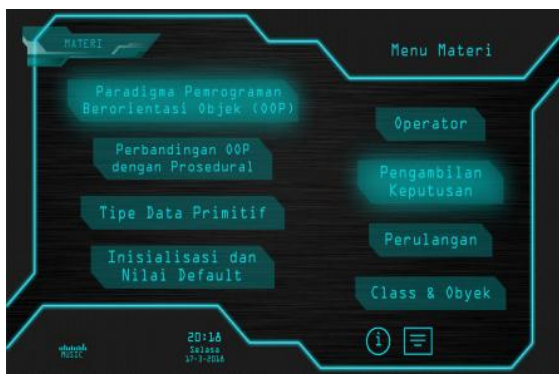

Gambar 4 Tampilan Halaman Materi

e. Halaman praktikum ini dirancang sebagai simulasi dari siswa untuk melakukan praktikum serta mempermudah siswa dalam memahami pengkodingan dasar pada bahasa pemrograman java, fitur yang terdapat pada halaman ini ialah tabulasi pengetikan listing program, serta tombol cek output untuk menampilkan output dari listing program, adapun gambarnya sebagai berikut.

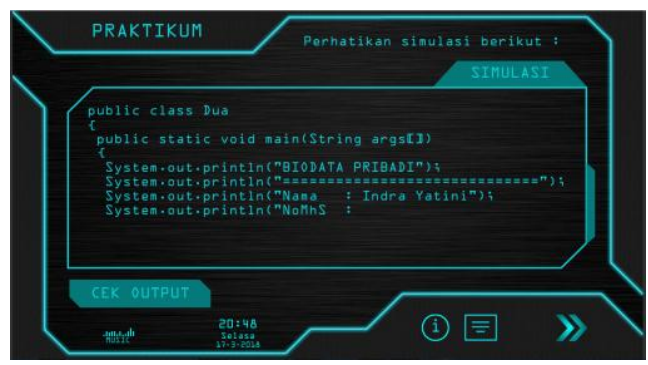

Gambar 5 Tampilan Halaman Simulasi Praktikum

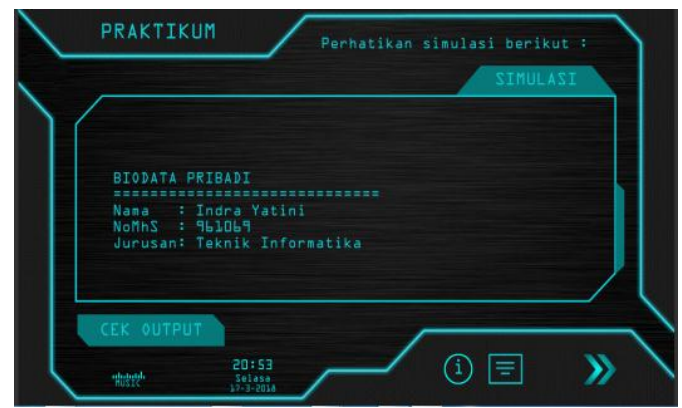

Gambar 6 Tampilan Halaman Simulasi Praktikum

Jika ditekan tombol panah next untuk mengarahkan kehalaman dimana siswa bisa mencoba mngetikkan sendiri contoh koding seperti tadi, berikut tampilannya seperti gambar, dan terdapat juga tombol mulai, lihat kode, dan ulangi.

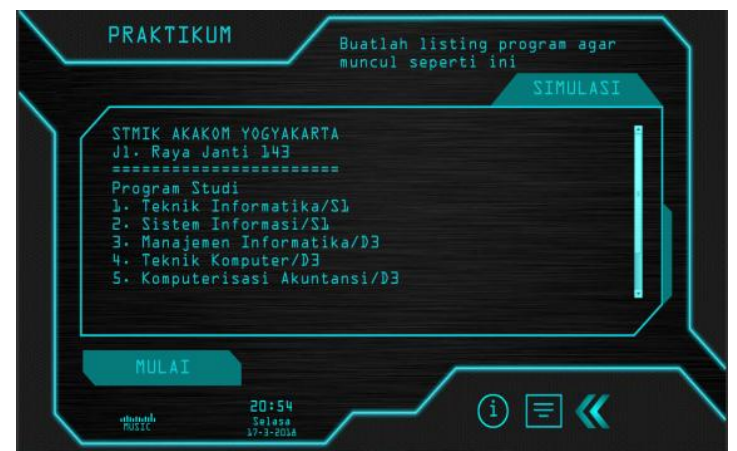

Gambar 7 Tampilan Halaman Simulasi Praktikum 


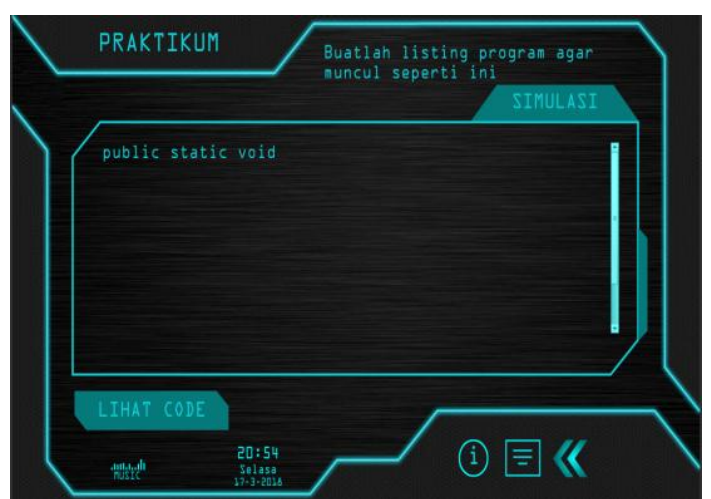

Gambar 8 Tampilan Halaman Simulasi Praktikum

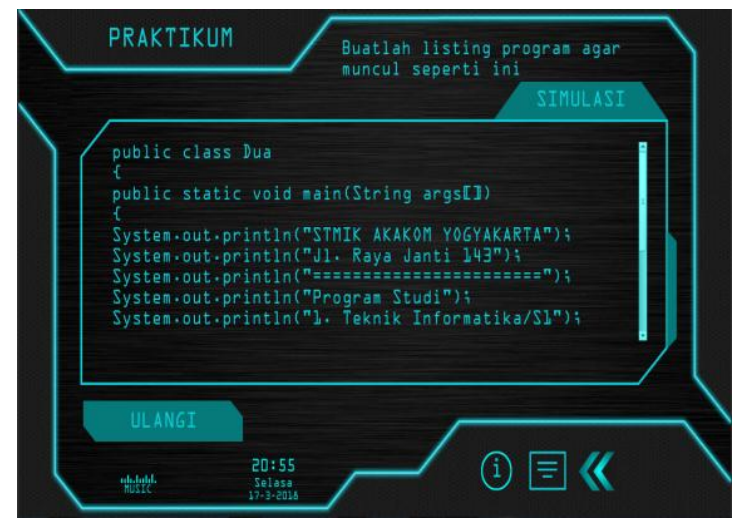

Gambar 9 Tampilan Halaman Simulasi Praktikum

f. Evaluasi ini dirancang menjadi lebih interaktif dengan memberikan feedback kepada siswa dapat dilihat pada gambar berikut ini:

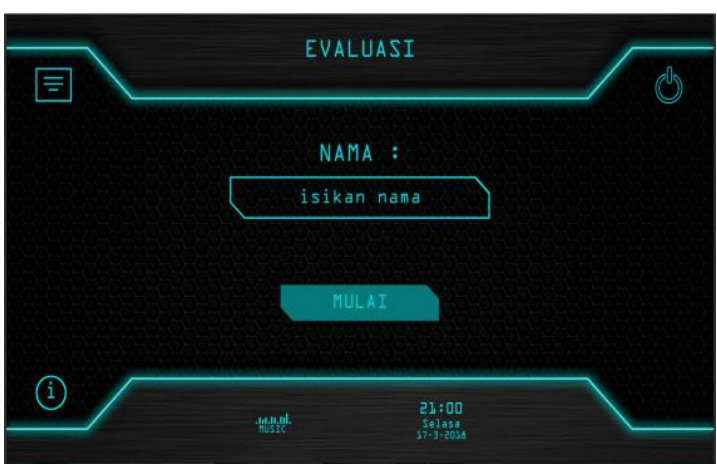

Gambar 10 Tampilan Halaman Evaluasi

Terlebih dahulu sebelum siswa memasuki halaman soal, siswa diperintahkan untuk mengisi nama pada saat awal membuka halaman evaluasi ini.

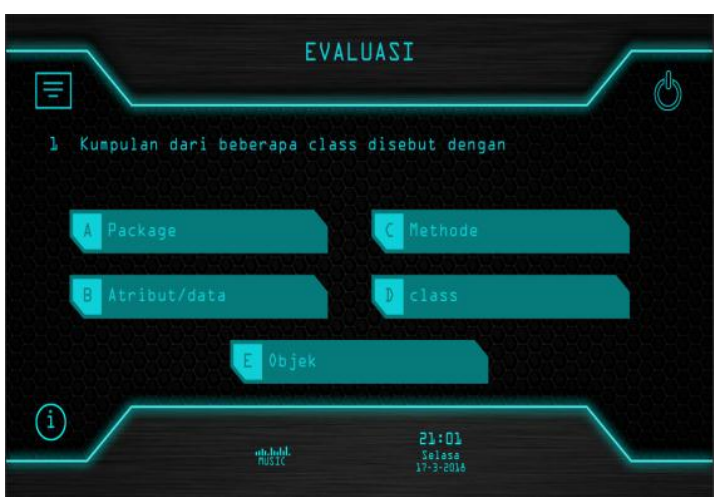

Gambar 11 Tampilan Halaman Evaluasi

Gambar di atas merupakan soal yang terdapat pada halaman evaluasi yang akan dijawab oleh siswa ketika berada dihalaman evaluasi, dan soal yang muncul menggunakan sistem random question artinya setiap siswa mengulang kembali evaluasi maka soal yang berbeda yang akan keluar.

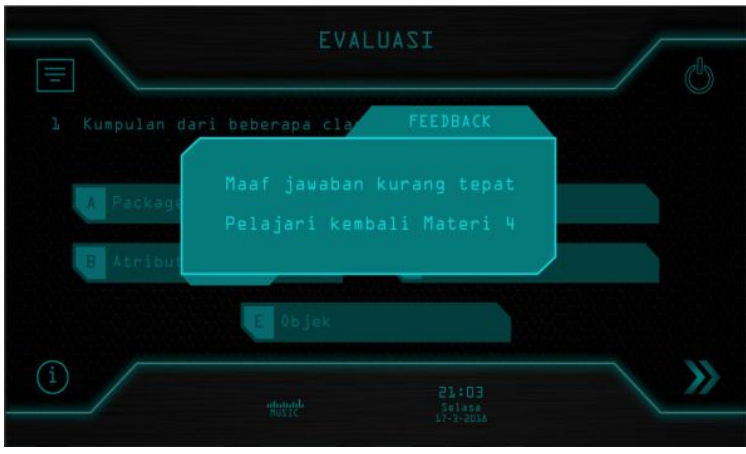

Gambar 12 Tampilan Halaman Evaluasi

Jika siswa menjawab soal dengan salah maka siswa akan menerima respon feedback dari modul pembelajaran interaktif ini, dan di instruksikan untuk mempelajari kembali materi yang sesuai dengan soal.

g. Halaman menu profil, dilihat padaa gambar di bawah ini.

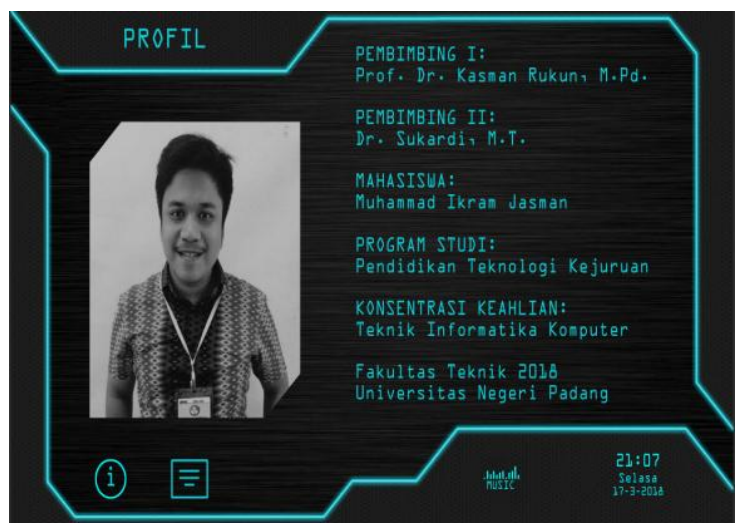

Gambar 13 Tampilan Halaman Profil 
h. Halaman petunjuk terdiri dari animasi teks dan layout petunjuk penggunaan Modul,.

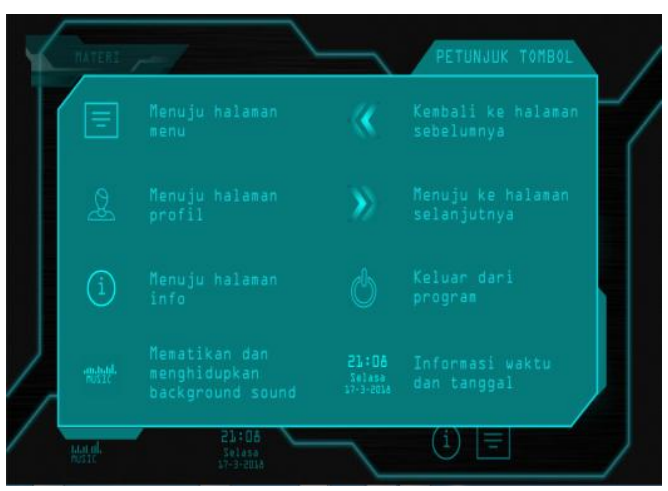

Gambar 14 Tampilan Halaman Petunjuk

\section{Tahap Pengembangan}

\section{Uji Validasi}

Tujuan dari validasi oleh ahli adalah untuk memperoleh masukan, kritik, dan saran perbaikan untuk kesempurnaan Modul yang dikembangkan. Data uji validasi diperoleh melalui instrumen validasi yang diisi oleh beberapa orang validator yang merupakan ahli Modul pembelajaran. Validator terdiri dari 5 orang yaitu tiga orang untuk validator modul dan dua orang untuk validator materi. Validasi ahli Modul difokuskan pada tampilan atau penyajian yang dilihat dari sudut pandang Modul. Validasi oleh ahli Modul bertujuan agar produk modul pembelajaran interaktif berbasis Adobe Flash CS6 yang dikembangkan menjadi produk yang berkualitas secara aspek pemograman dan tampilan.

Data dari validator diperoleh dari angket yang telah diberikan penilaian oleh tiga orang validator. Validator pertama, kedua dan ketiga memberikan nilai rata-rata sebesar 0,89 , sehingga dapat dikatakan bahwa desain modul pembelajaran interaktif ini valid. Berdasarkan saran dan penilaian dari validator baik dari segi isi dan desain maka dilakukan revisi terhadap modul pembelajaran interaktif ini, sehingga modul pembelajaran interaktif yang dikembangkan layak untuk diujicobakan.

Dari hasil validasi materi oleh ahli dapat diketahui bahwa modul pembelajaran interaktif yang telah dikembangkan mencapai kategori valid dengan skor rata-rata kevalidan sebesar 0,89 . Hasil penilaian ini juga sejalan dengan hasil-hasil penelitian yang terdahulu yang dilakukan oleh Nuryadin Eko Raharjo (2011) yang menunjukkan persentase hasil pencapaian skor rata-rata sebesar $85,34 \%$ dalam kategori sangat valid, sehingga dilihat dari segi kebenaran ketepatan materi dalam Modul, Modul pembelajaran interaktif tersebut layak untuk diujicobakan di lapangan.

\section{Kepraktisan Modul Pembelajaran Interaktif}

Data kepraktisan modul pembelajaran interaktif diambil melalui uji yang dilakukan di SMK Negeri 1 Lahat yang bertujuan untuk melihat keterlaksanaan pembelajaran dengan menggunakan modul pembelajaran interaktif ini. Untuk melihat kepraktisan, modul pembelajaran interaktif yang telah valid digunakan dalam proses pembelajaran oleh guru. Di akhir pembelajaran, guru dan siswa diminta mengisi angket kepraktisan dari modul pembelajaran interaktif yang telah digunakan.

Penilaian terhadap kepraktisan modul pembelajaran interaktif ini diperoleh dari angket yang diisi oleh guru praktisi dan hasil penilaian yang diperoleh dari angket respon guru terhadap praktikalitas modul pembelajaran interaktif ini adalah sebesar 93,33\% dengan kategori kepraktisan sangat praktis. Selain penilaian dari guru/praktisi, kepraktisan modul pembelajaran interaktif ini juga dinilai berdasarkan tanggapan siswa dan hasil diketahui pada angket respon siswa yaitu diperoleh nilai sebesar $87,50 \%$ sehingga dapat disimpulkan bahwa modul pembelajaran interaktif yang dikembangkan adalah praktis dengan kategori kepraktisan sangat praktis.

Hasil uji coba ini sejalan dengan hasil penelitian terdahulu yang dilakukan oleh Nuryadin Eko Raharjo (2011) yang menunjukkan pencapaian persentase sebesar $85,34 \%$ dalam kategori sangat praktis dan penelitian Nurul Machfudhoh (2016) yang menunjukkan hasil dari respon siswa dengan pencapaian persentase sebesar 90,25\% dalam kategori sangat praktis.

\section{Efektivitas Modul Pembelajaran Interaktif}

Keefektifan modul pembelajaran interaktif pada penelitian ini dilihat digunakan untuk memudahkan siswa dalam memahami materi pembelajaran, serta keefektifan dari modul pembelajaran interaktif yang digunakan dapat dilihat dari hasil belajar kognitif siswa. Hasil belajar adalah kemampuan yang dimiliki siswa setelah mereka melalui proses pengalaman belajar. Hasil belajar didapatkan dari pretest dan postest 28 orang siswa yang diberikan dalam bentuk tes objektif sebanyak 25 butir soal. Berdasarkan data yang diperoleh dari hasil uji modul pembelajaran interaktif ini maka peneliti dapat menjelaskan bahwa terdapat perbedaan yang signifikan pada hasil kelas pre test dan post test. Berdasarkan tabel 4.10 menunjukkan bahwa 80,25\% telah mencapai KKM.

Hasil penelitian ini relevan dengan penelitian yang dilakukan Deno (2016) yang memperoleh hasil uji efektivitas hasil belajar siswa sebesar $78,2 \%$ 
dalam kategori baik yang diperoleh dari penilaian hasil belajar secara kognitif siswa dari pre test dan post test, dijelaskan bahwa siswa yang belum tuntas $(\mathrm{KKM}<75)$ adalah sebanyak 7 siswa $(21,8 \%)$ dan yang telah mencapai KKM sebanyak 25 siswa $(78,2 \%)$ dan ketuntasan klasikalnya dikategorikan baik, sehingga dapat disimpulkan bahwa Modul pembelajaran interaktif ini efektif. Nuryadin Eko Raharjo (2011) dengan persentase keefektivan sebesar $87,18 \%$, siswa dapat nilai di atas KKM, sedangkan $12,82 \%$ belum mencapai KKM. Sehingga dilihat dari hasil belajar kognitif siswa yang mengikuti pelajaran dengan menggunakan modul pembelajaran interaktif, menunjukkan bahwa modul pembelajaran interaktif yang dikembangkan peneliti efektif untuk meningkatkan hasil belajar siswa.

\section{Tahap Penyebaran (Disseminate)}

Tahap penyebarluasan atau diseminasi dilakukan dengan cara penerapan modul pembelajaran interaktif ini didalam proses belajar mengajar pada mata pelajaran OOP khususnya pada kompetensi dasar Memahami konsep OOP yang disebarkan pada kelas lain yaitu kelas XI RPL SMK Negeri 1 Lahat. Penyebaran dapat juga dilakukan melalui sebuah proses penularan kepada praktisi pembelajaran terkait dalam suatu forum tertentu. Berdasarkan penjelasan di atas, dapat disimpulkan bahwa Modul Pembelajaran Interaktif ini merupakan salah satu modul ujian yang valid, praktis, dan efektif untuk digunakan dalam proses pembelajaran . Hal ini sesuai dengan pendapat Thiagarajan (1974) "Tahap desiminasi dilakukan untuk mempomosikan produk pengembangan agar bisa diterima pengguna, baik individu, suatu kelompok atau sistem", pada tahap ini dilakukan secara offline dengan nama Produk Modul Pembelajaran Interaktif Aplikasi Adobe Flash Bahasa Java Pada Mata Pelajaran Object Oriented Programming (OOP).

\section{KESIMPULAN}

Berdasarkan hasil analisis dan pembahasan data penelitian yang telah dilakukan oleh peneliti, dapat disimpulkan bahwa pengembangan ini menghasilkan sebuah modul pembelajaran interaktif valid, praktis dan efektif, pada mata pelajaran OOP kelas XI Jurusan RPL, hal ini dibuktikan karena modul pembelajaran interaktif ini telah mengalami uji coba validitas, praktikalitas dan efektifitas yang dilakukan terhadap validator, guru dan siswa. Modul pembelajaran interaktif yang dikembangkan ini didasarkan pada standar kompetensi, dan kompetensi dasar dari mata pelajaran OOP.

\section{DAftar Pustaka}

[1] A. Yulastri, H. Hidayat, Ganefri, S. Islami, and F. Edya, "Developing an Entrepreneurship Module by Using Product-Based Learning Approach in Vocational Education," Int. J. Environ. Sci. Educ., vol. 12, no. 5, pp. 1097-1109, 2017.

[2] R. E. Wulansari, D. Puyada, I. Wijaya, and K. Rukun, "EFFECTIVENESS OF INSTRUCTIONAL MEDIA BASED GAME ON MATHEMATICS AT VOCATIONAL HIGH SCHOOL," Int. J. Res. Sci. Manag., vol. 4, no. 12, pp. 125-128, 2017.

[3] M. A. Zaus, R. E. Wulansari, S. Islami, and D. Pernanda, "PERANCANGAN MEDIA PEMBELAJARAN LISTRIK STATIS DAN DINAMIS BERBASIS ANDROID," INTECOMS J. Inf. Technol. Comput. Sci., vol. 1, no. 1, pp. 1-7, Mar. 2018.

[4] S. Sukardi, D. Puyada, R. E. Wulansari, and D. T. P. Yanto, "The validity of interactive instructional media on electrical circuits at vocational high school and technology," in the 2nd INCOTEPD, 2017, vol. 2017, no. October, pp. 21-22.

[5] D. Pernanda, M. A. Zaus, R. E. Wulansari, and S. Islami, "Effectiveness of instructional media based on interactive cd learning on basic network at vocational high school: improving student cognitive ability Effectiveness of instructional media based on interactive cd learning on basic network at vocational hig," Int. Conf. Educ. Soc. Sci. Technol., no. February, 2018.

[6] M. A. Zaus, "Suatu Kajian Literatur MasalahMasalah yang Dihadapi dalam Mata Kuliah Jaringan Komputer," vol. 18, no. 1, pp. 1-8, 2018.

[7] N. Jalinus, Syahril, and R. A. Nabawi, "Effectivity of The Cooperative-Project Based Learning ( CPjBL ) in Enhancing HOTS of Vocational Education Students," no. 1, pp. 83-86, 2018.

[8] R. Lapisa, I. Y. Basri, A. Arif, and H. D. Saputra, "PENINGKATAN KOMPETENSI SISWA MELALUI PELATIHAN AUTO CAD," vol. 17, no. 2, 2017.

[9] D. Pernanda, M. A. Zaus, R. E. Wulansari, and S. Islami, "Effectiveness of instructional media based on interactive cd learning on basic network at vocational high school: improving student cognitive ability," Int. Conf. Educ. Soc. Sci. Technol., no. January, pp. 440-444, 2018.

[10] M. A. Zaus, R. E. Wulansari, S. Islami, and D. Pernanda, "Perancangan Media Pembelajaran Listrik Statis dan Dinamis Berbasis Android," vol. 1, no. 1, pp. 1-7, 2018.

[11] Mariyana, Herpratiwi, and I. W. Mustika, "Pengembangan Modul Pembelajaran Tari Piring Dua Belas di SMA Bandar Lampung," FKIP Unila, no. 1, 2010. 
[12] D. Pendidikan, "2008," 2008.

[13] S. S. Pd, S. D. Negeri, and K. Banda, "Sulastri *," vol. 22, no. September, pp. 200-210, 2015.

[14] W. Harlen, C. Gipps, P. Broadfoot, and D. Nuttall, "Assessment and the improvement of education," Curric. J., vol. 3, no. 3, pp. 215-230, 1992.

[15] Hashimah Mohd. Yunus, Zurida Ismail, and George Raper, "Malaysian Primary Teachers ' Classroom Practice of Teaching and Learning Science," J. Sci. Math. Educ. S.E. Asia, vol. 27, no. 1, pp. 166-203, 2004

[16] P. E. Susanty and E. Kusumasturi, "Model Pembelajaran Interaktif Kelompok pada Mata Pelajaran Seni," JOGED J. Seni Tari, vol. 3, no. 1, pp. 36-48, 2012.

[17] S. Siagian, "DEVELOPMENT OF BASIC ELECTRONIC INSTRUCTIONAL MODULE AND TRAINER Sahat Siagian Panahatan, Jongga Manullang, State University of Medan," Eur. J. Comput. Sci. Inf. Technol., vol. 2, no. 3, pp. 36-46, 2014.

[18] J. W. J. Robinson and W. B. Crittenden, "Learning Modules: A Concept for Extension Educators?," Journal of Extension (Winter). pp. 35-44, 1972.

[19] A. Account, P. Supported, and D. Committee, Development in Education Projects 1994-2000
Development in Education Projects 1994-2000. 2000.

[20] T. Litay, W.Mataheru, and H.Tamalene, PENGEMBANGAN PERANGKAT PEMBELAJARAN KOOPERATIF TIPE TEAM ASSISTED INDIVIDUALIZATION (TAI) PADA MATERI KESEBANGUNAN SEGITIGA DI KELAS IX SMP KRISTEN YPKPM AMBON. 2016.

\section{Biodata Penulis}

Muhammad Ikram Jasman, lahir di Padang, 26 April 1992. Sarjana Pendidikan di Jurusan Teknik Informatika Komputer FKIP UBH 2015. Tahun 2018 memperoleh gelar Magister Pendidikan Teknik di jurusan Teknologi Pendidikan Program Pascasarjana UNP dengan bidang konsentrasi Pendidikan Teknik Informatika Komputer. Staf pengajar di jurusan Teknik Rekayasa Perangkat Lunak SMK N 1 Lahat sejak tahun 2015- sekarang. 